The Canadian Mineralogist

Vol. 42, pp. 723-729 (2004)

\title{
THE CRYSTAL STRUCTURE OF STURMANITE
}

\author{
Dmitry Yu. PUSHCHAROVSKY ${ }^{\S}$, Yulia S. LEBEDEVA and Natalia V. ZUBKOVA \\ Faculty of Geology, Moscow State University, Vorobievy Gory, RU-119899 Moscow, Russia \\ Marco PASERO ${ }^{\mathbb{I}}$, Marco BELLEZZA and Stefano MERLINO \\ Dipartimento di Scienze della Terra, Università degli Studi di Pisa, via S. Maria 53, I-56126 Pisa, Italy \\ NIKITA V. CHUKANOV \\ Institute of Chemical Physics Problems, RU-142432 Chernogolovka, Moscow Oblast, Russia
}

\begin{abstract}
Sturmanite, ideally $\mathrm{Ca}_{6} \mathrm{Fe}^{3+}{ }_{2}\left(\mathrm{SO}_{4}\right)_{25}\left[\mathrm{~B}(\mathrm{OH})_{4}\right](\mathrm{OH})_{12} \cdot 25 \mathrm{H}_{2} \mathrm{O}$, is trigonal, $P 31 c, Z=2$, with $a$ 11.188(9), $c$ 21.91(7) $\AA$, $V$ 2375.1(5) $\AA^{3}$. The crystal structure has been refined to an $R$ index of 0.079 . As in the case of ettringite, two coaxial elements parallel to [001] can be considered as the most distinctive features of sturmanite. The main one is a column of polyhedra formed by Fe-octahedra and Ca-polyhedra. The $\mathrm{Fe}(\mathrm{OH})_{6}$ octahedra are located along the three-fold axes that pass through the origin of the cell. They are linked to three ${ }^{\mathrm{VIII}} \mathrm{Ca}$-polyhedra, located around the three-fold axes, in between the $\mathrm{Fe}(\mathrm{OH})_{6} \mathrm{Octahedra}$. The second structural element parallel to $[001]$ contains $\left[\mathrm{SO}_{4}\right]$ and $\mathrm{B}(\mathrm{OH})_{4}$ tetrahedra; it is located along three-fold axes at $(1 / 3,2 / 3, z)$ and $(2 / 3,1 / 3, z)$. Both structural modules are linked to each other by a complex system of hydrogen bonds. On the basis of a complete determination of the structure, the chemical composition of sturmanite is close to $\mathrm{Ca}_{6}\left[\mathrm{Fe}^{3+}{ }_{0.6} \mathrm{Al}_{0.2} \mathrm{Mn}^{4+}{ }_{0.2}\right]_{2}$ $\left[\mathrm{SO}_{4}\right]_{2.7}\left[\mathrm{~B}(\mathrm{OH})_{3}\right]_{0.3}\left[\mathrm{~B}(\mathrm{OH})_{4}\right](\mathrm{OH})_{12} \cdot 24 \mathrm{H}_{2} \mathrm{O}$.
\end{abstract}

Keywords: sturmanite, crystal structure, boron coordination, Black Rock mine, South Africa.

\section{SOMMAIRE}

La sturmanite, de composition idéale $\mathrm{Ca}_{6} \mathrm{Fe}^{3+}{ }_{2}\left(\mathrm{SO}_{4}\right)_{2.5}\left[\mathrm{~B}(\mathrm{OH})_{4}\right](\mathrm{OH})_{12} \cdot 25 \mathrm{H}_{2} \mathrm{O}$, est trigonale, $P 31 c, Z=2, a 11.188(9), c$ 21.91(7) $\AA$, et $V 2375.1(5) \AA^{3}$. Nous en avons affiné la structure jusqu'à un résidu $R$ de 0.079 . Tout comme pour l'ettringite, les aspects les plus distinctifs de la sturmanite sont deux éléments coaxiaux parallèles à [001]. L'élément principal est une colonne de polyèdres formée d'octaèdres $\mathrm{Fe}$ et de polyèdres $\mathrm{Ca}$. Les octaèdres $\mathrm{Fe}(\mathrm{OH})_{6}$ sont situés le long d'axes de rotation trois à l'origine de la maille. Ils sont agencés avec trois polyèdres contenant le ${ }^{\mathrm{VIII}} \mathrm{Ca}$, situés autour des mêmes axes entre les octaèdres $\mathrm{Fe}(\mathrm{OH})_{6}$. Le deuxième élément structural parallèle à [001] implique les tétraèdres $\left[\mathrm{SO}_{4}\right]$ et $\mathrm{B}(\mathrm{OH})_{4}$; il est situé le long d'axes de rotation trois aux sites $(1 / 3,2 / 3, z)$ et $(2 / 3,1 / 3, z)$. Les deux modules structuraux sont interliés selon un système complexe de liaisons hydrogène. $\mathrm{D}$ 'après notre détermination complète de la structure, la composition chimique de la sturmanite serait voisine de $\mathrm{Ca}_{6}\left[\mathrm{Fe}^{3+}{ }_{0.6} \mathrm{Al}_{0.2} \mathrm{Mn}^{4+}{ }_{0.2}\right]_{2}\left[\mathrm{SO}_{4}\right]_{2.7}\left[\mathrm{~B}(\mathrm{OH})_{3}\right]_{0.3}\left[\mathrm{~B}(\mathrm{OH})_{4}\right](\mathrm{OH})_{12} \cdot 24 \mathrm{H}_{2} \mathrm{O}$.

(Traduit par la Rédaction)

Mots-clés: sturmanite, structure cristalline, coordinence du bore, mine Black Rock, Afrique du Sud.

\section{INTRODUCTION}

Sturmanite was originally discovered in association with barite in a specimen from the Black Rock manganese mine, Kuruman District, Kalahari manganese field, North Cape province, South Africa (Peacor et al. 1983).
Its ideal chemical formula is $\mathrm{Ca}_{6} \mathrm{Fe}^{3+}{ }_{2}\left(\mathrm{SO}_{4}\right)_{2.5}\left[\mathrm{~B}(\mathrm{OH})_{4}\right]$ $(\mathrm{OH})_{12} \cdot 25 \mathrm{H}_{2} \mathrm{O}$. Sturmanite is the ferric-iron-dominant, boron-containing analogue of ettringite, $\mathrm{Ca}_{6} \mathrm{Al}_{2}\left(\mathrm{SO}_{4}\right)_{3}$ $(\mathrm{OH})_{12} \cdot 26 \mathrm{H}_{2} \mathrm{O}$ (Moore \& Taylor 1970), and belongs to the thaumasite-ettringite mineralogical group. Like two other boron-bearing ettringite-group minerals, buryatite

$\S \quad$ E-mail address: dmitp@geol.msu.ru
II $\quad$ E-mail address: pasero@dst.unipi.it 
and charlesite (Table 1), it forms flattened dipyramidal crystals, the main forms being $\{10 \overline{1} 4\}$ for sturmanite and charlesite, and $\{0001\}$ for buryatite, whereas prismatic crystals are more common among boron-free members of the group. According to Pöllmann et al. (1989) and Merlino \& Orlandi (2001), two distinct subgroups exist within the thaumasite-ettringite group, the first with tetravalent cations ( $\mathrm{Si}, \mathrm{Mn}, \mathrm{Ge}$ ) and hexagonal symmetry, the second with trivalent cations $(\mathrm{Al}, \mathrm{Cr}$, $\mathrm{Fe}$ ) and trigonal symmetry. Thaumasite, jouravskite and carraraite are the members of the first subgroup, whereas ettringite, bentorite, sturmanite, charlesite and buryatite belong to the second one. Among the minerals of the latter subgroup, ettringite is the only one whose structure has been reported so far (Moore \& Taylor 1970). Therefore, a structural investigation of sturmanite is highly desirable, especially if one considers that the chemical formula of sturmanite given by Peacor et al. (1983), $\mathrm{Ca}_{6}\left(\mathrm{Fe}^{3+}{ }_{1.5} \mathrm{Al}_{0.3} \mathrm{Mn}^{2+}{ }_{0.2}\right)\left(\mathrm{SO}_{4}\right)_{2.3}\left[\mathrm{~B}(\mathrm{OH})_{4}\right]_{1.2}$ $(\mathrm{OH})_{12} \cdot 25 \mathrm{H}_{2} \mathrm{O}$, is tentative and was obtained as a result of analyses of impure material. In particular, the contents of boron, sulfur and $\mathrm{Mn}^{2+}$ in sturmanite seem problematic, and raise doubts that can be solved only through crystal-structure information. Besides, sturmanite represents the first boron-bearing ettringite-group mineral to be studied structurally. Two other boron-bearing members of this group, namely charlesite (with $\mathrm{B}+\mathrm{Al}$ ) and the recently discovered buryatite (with $\mathrm{B}+\mathrm{Si}$ ), apparently do not form crystals suitable for structural study (Dunn et al. 1983, Malinko et al. 2001).

A new discovery of sturmanite from its type locality in Black Rock mine has provided crystals of better quality (Fig. 1) than the holotype specimen, and stimulated us to carry out this structural study.

\section{EXPERIMENTAL}

Preliminary chemical analyses of the new samples of sturmanite were carried out by means of an energydispersion X-ray spectrometer (electron microprobe CAMEBAX-MBX combined with a Link AN 10000 energy-dispersion spectrometer). The results obtained led to the following ranges for the main constituents of

TABLE 1. BORON-CONTAINING MFMBERS OF THE ETTRINGITE GROUP

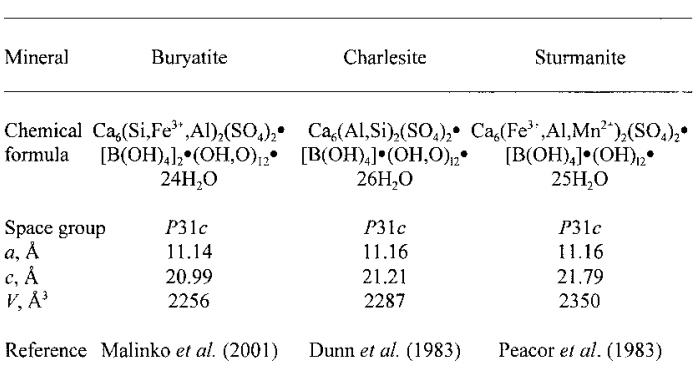

sturmanite: $\mathrm{Ca}_{6}\left(\mathrm{Fe}_{1.3-1.4} \mathrm{Mn}_{0.2-0.4} \mathrm{Al}_{0.1-0.3}\right)\left(\mathrm{SO}_{4}\right)_{2.1-2.6}$ $\left(\mathrm{SiO}_{4}\right)_{0-0.1}\left[\mathrm{~B}(\mathrm{OH})_{4}\right]_{x}(\mathrm{OH})_{12} \cdot 25 \mathrm{H}_{2} \mathrm{O}$. An evaluation of infrared (IR) spectra of samples with a known content of $\mathrm{B}$ gave $x \approx 1$.

The single-crystal X-ray-diffraction study, initially carried out with rotation and Weissenberg photographs, and followed by collection of intensity data with an Ital Structures four-circle diffractometer, showed the crystals to be trigonal, space group $P 31 c$, with unit-cell dimensions $a$ 11.188(9), $c$ 21.91(7) Å. Details of the X-ray data collection and structure refinement of sturmanite are given in Table 2.

The structure was refined using the SHELX-97 program (Sheldrick 1997) with starting parameters taken from ettringite (Moore \& Taylor 1970). Most of the atom positions confirm the general model of ettringite, and the $R$ factor at an initial stage was 0.12 . However, several specific features of sturmanite were revealed during the cycles of least-square refinement. In particular, we first introduced the $S(1)$ atom and its ligands with full occupancy, but after some cycles of refinement the values of the displacement parameters indicated that the $\mathrm{S}(1)$ is incompletely filled. Eventually, the occupancy factor of that site was set to 0.7 and, at the same time, a new $\mathrm{B}(1)$ site with the occupancy 0.3 was included in the center of the bases of the tetrahedron. Thus $\mathrm{B}(1)$ is in triangular coordination, as a $\left[\mathrm{B}(\mathrm{OH})_{3}\right]$ group. The almost regular tetrahedral coordination around the $\mathrm{S}(3)$ site is consistent with $\mathrm{S}$ atoms only located in its center. Besides, the difference-Fourier map showed up new sites, attributed to boron and its ligands (oxygen atoms in tetrahedral coordination). In the process of refinement, it became evident that some atoms of oxygen belonging to the $\left[\mathrm{S}(2) \mathrm{O}_{4}\right]$ tetrahedron and the $\left[\mathrm{B}(4)(\mathrm{OH})_{4}\right]$

TABLE 2. DATA COLLECTION AND REFINEMENT DATA FOR STURMANITE

\begin{tabular}{|c|c|}
\hline Chemical formula & $\begin{array}{l}\mathrm{Ca}_{6}\left[\mathrm{Fe}_{0.6} \mathrm{Al}_{\mathrm{O}_{2}} \mathrm{Mn}^{4}{ }_{0.2}\right]_{2}\left(\mathrm{SO}_{4}\right)_{2.7} \\
\left.\left[\mathrm{~B}(\mathrm{OH})_{3}\right]_{07} / \mathrm{B}(\mathrm{OH})_{4}\right](\mathrm{OH})_{2}=24 \mathrm{H}_{2} \mathrm{O}\end{array}$ \\
\hline Unit-formula weight & 2533.74 \\
\hline Radiation and wavelength, $\AA$ & MoK $\alpha ; 0.71069$ \\
\hline$\mu, \mathrm{mm}^{1}$ & 1.43 \\
\hline Diffractometer; monochromator & Ital Structures; graphite \\
\hline Space group; $Z$ & $P 31 c ; 2$ \\
\hline Unit-cell dimensions, $\AA$ & $a 11.188(9), c 21.91(7)$ \\
\hline Unit-cell volume, $\AA^{3}$ & $2375.1(5)$ \\
\hline$F(000)$ & 1258 \\
\hline$D($ calc. $), \mathrm{g} / \mathrm{cm}^{3}$ & 1.77 \\
\hline Crystal size, $\mathrm{mm}$ & $0.42 \times 0.25 \times 0.16$ \\
\hline Index ranges & $-12 \leq h \leq 3,-13 \leq k \leq 4,-30 \leq l \leq 29$ \\
\hline Standard reflection & Every 100 reflections \\
\hline Collected reflections & 1811 \\
\hline \multicolumn{2}{|l|}{ Independent reflections } \\
\hline with $I>2 \sigma(I)$ & $977 ; R_{\text {int }}=0.096$ \\
\hline Refinement method & Full-matrix least-squares on $F^{2}$ \\
\hline Weights & $\begin{array}{l}1 /\left[\sigma^{2}\left(\mathrm{~F}_{\mathrm{o}}^{2}\right)+(0.1195 \mathrm{P})^{2}+10.99 \mathrm{P}\right] \\
\mathbf{P}=\left[\max \left(\mathrm{F}_{\mathrm{o}}\right)^{2}+2\left(\mathrm{~F}_{\mathrm{c}}\right)^{2}\right] / 3\end{array}$ \\
\hline$R(F), R\left(F^{2}\right), \mathrm{GoF}$ & $0.079 ; 0.196 ; 1.141$ \\
\hline Number of refined parameters & 201 \\
\hline Largest residues $\left(e^{-/ \AA^{3}}\right)$ & $+1.68 ;-0.95$ \\
\hline
\end{tabular}

Numbers in parentheses represent the e.s.d. referred to the last digit 
tetrahedra are split. As both cations lie on the threefold axes, the splitting arose from $60^{\circ}$ rotation of the basal plane. Moreover, in both cases, inverted, upside-down tetrahedra were observed. In the case of $S(2)$, an inverted tetrahedron is formed by one $\mathrm{O}\left(14^{\prime}\right)$ and three $\mathrm{O}\left(17^{\prime}\right)$ as the ligands, whereas in the case of $\mathrm{B}(4)$, an inverted tetrahedron is formed by one $\mathrm{O}\left(20^{\prime}\right)$ and three $\mathrm{O}\left(19^{\prime}\right)$. These features were accounted for during the refinement. The presence of $\left[\mathrm{B}(\mathrm{OH})_{4}\right]$ tetrahedra was confirmed in the IR spectrum, which contains a band in the interval $940-1000 \mathrm{~cm}^{-1}$ assigned to $\mathrm{B}-\mathrm{O}$ stretching vibrations of the $\left[\mathrm{B}(\mathrm{OH})_{4}\right]$ tetrahedra (Pöllmann et al. 1989).

The scattering power of both octahedral sites [22.6e for $\mathrm{Fe}(1)$ and $23.4 e$ for $\mathrm{Fe}(2)]$ corresponds to partial $\mathrm{Fe}-\mathrm{Al}-\mathrm{Mn}$ occupancy. The (Fe, $\mathrm{Al})$ : $\mathrm{Mn}$ ratio was taken from the chemical data, and the Al content in both sites was obtained from a refinement of their occupancies. As a first approach, one can assume an equal content of $\mathrm{Al}$ in both octahedral sites. The calculated scattering power $(23.2 e)$ in this case fits well with those obtained

TABLE 3. ATOM COORDINATES, ATOMIC-DISPLACEMENT PARAMETERS, AND OCCUPANCY COEFFICIENTS (WHERE REFNED) FOR STURMANITE

\begin{tabular}{|c|c|c|c|c|c|}
\hline Atom & $x$ & $y$ & $z$ & s.o.f. & $U_{\mathrm{eq}} / U_{\mathrm{iso}}\left(\AA^{2}\right)$ \\
\hline $\mathrm{Fe}(1)$ & 0 & 0 & $0.0527(2)$ & 0.29 & $0.0162(2)$ \\
\hline $\mathrm{Fe}(2)$ & 0 & 0 & $0.3015(2)$ & 0.30 & $0.0174(2)$ \\
\hline $\mathrm{Ca}(1)$ & $0.0088(1)$ & $0.8133(1)$ & $0.9276(1)$ & & $0.0224(3)$ \\
\hline $\mathrm{Ca}(2)$ & $0.9966(1)$ & $0.1941(1)$ & $0.1775(1)$ & & $0.0298(3)$ \\
\hline $\mathrm{S}(1)$ & $1 / 3$ & $2 / 3$ & $0.5454(1)$ & 0.24 & $0.0177(7)$ \\
\hline $\mathrm{B}(1)$ & $1 / 3$ & $2 / 3$ & $0.5378(4)$ & 0.09 & $0.020^{*}$ \\
\hline $\mathrm{S}(2)$ & $1 / 3$ & $2 / 3$ & $0.8032(1)$ & & $0.0253(5)$ \\
\hline$S(3)$ & $1 / 3$ & $2 / 3$ & $0.0571(1)$ & & $0.0341(8)$ \\
\hline $\mathrm{B}(4)$ & $1 / 3$ & $2 / 3$ & $0.3036(1)$ & & $0.049(5)$ \\
\hline$O(1)$ & $0.9911(5)$ & $0.1295(4)$ & $0.9935(2)$ & & $0.028(1)$ \\
\hline$O(2)$ & $1.0077(5)$ & $0.8616(4)$ & $0.1070(2)$ & & $0.024(1)$ \\
\hline$O(3)$ & $-0.0028(4)$ & $0.1371(4)$ & $0.8609(2)$ & & $0.024(1)$ \\
\hline $\mathrm{O}(4)$ & $0.0057(5)$ & $0.8691(5)$ & $0.2456(2)$ & & $0.041(2)$ \\
\hline$O(5)$ & $0.0023(4)$ & $0.3355(5)$ & $0.0986(2)$ & & $0.041(1)$ \\
\hline$O(6)$ & $0.0157(4)$ & $0.6591(5)$ & $1.0077(2)$ & & $0.040(1)$ \\
\hline$O(7)$ & $0.9939(6)$ & $0.3553(6)$ & $0.2560(3)$ & & $0.075(2)$ \\
\hline $\mathrm{O}(8)$ & $0.9952(5)$ & $0.6660(5)$ & $0.8428(2)$ & & $0.034(1)$ \\
\hline$O(9)$ & $0.2655(6)$ & $0.4111(5)$ & $0.6759(2)$ & & $0.056(2)$ \\
\hline$O(10)$ & $0.7416(5)$ & $0.5858(5)$ & $0.4296(2)$ & & $0.036(1)$ \\
\hline$O(11)$ & $0.2397(4)$ & $0.3986(4)$ & $0.1820(2)$ & & $0.038(1)$ \\
\hline$O(12)$ & $0.7393(8)$ & $0.5784(7)$ & $0.9240(3)$ & & $0.084(3)$ \\
\hline$O(13)$ & $1 / 3$ & $2 / 3$ & $0.4816(1)$ & 0.24 & $0.135(9)$ \\
\hline$O(14)$ & $1 / 3$ & $2 / 3$ & $0.7369(2)$ & 0.17 & $0.046(3)$ \\
\hline$O\left(14^{\prime}\right)$ & $1 / 3$ & $2 / 3$ & $0.8694(2)$ & 0.17 & $0.046(3)$ \\
\hline$O(15)$ & $1 / 3$ & $2 / 3$ & $0.1218(1)$ & & $0.017(2)$ \\
\hline$O(16)$ & $0.1995(3)$ & $0.6326(4)$ & $0.5671(2)$ & & $0.025(1)$ \\
\hline$O(17)$ & $0.1914(4)$ & $0.579(1)$ & $0.8233(3)$ & 0.50 & $0.044(2)$ \\
\hline $\mathrm{O}\left(17^{\prime}\right)$ & $0.1963(9)$ & $0.632(1)$ & $0.7728(4)$ & 0.50 & $0.044(2)$ \\
\hline$O(18)$ & $0.1917(7)$ & $0.5844(9)$ & $1.0421(5)$ & & $0.169(4)$ \\
\hline$O(19)$ & $0.2325(3)$ & $0.7100(4)$ & $0.2816(2)$ & 0.50 & $0.076(3)$ \\
\hline$O\left(19^{\prime}\right)$ & $0.1861(4)$ & $0.572(1)$ & $0.3248(2)$ & 0.50 & $0.076(3)$ \\
\hline$O(20)$ & $1 / 3$ & $2 / 3$ & $0.3702(1)$ & 0.17 & $0.091^{*}$ \\
\hline$O\left(20^{\prime}\right)$ & $1 / 3$ & $2 / 3$ & $0.2363(1)$ & 0.17 & $0.091^{*}$ \\
\hline
\end{tabular}

Numbers in parentheses represent the e.s.d. referred to the last digit. $U_{\text {iss }}$ values are marked with an asterisk; s.o.f.: site-occupancy factor. from the refinement of the occupancies. Thus the complete determination of the structure led to the following chemical composition of sturmanite: $\mathrm{Ca}_{6}\left[\mathrm{Fe}_{0.6} \mathrm{Al}_{0.2}\right.$ $\left.\mathrm{Mn}_{0.2}\right]_{2}\left[\mathrm{SO}_{4}\right]_{2.7}\left[\mathrm{~B}(\mathrm{OH})_{3}\right]_{0.3}\left[\mathrm{~B}(\mathrm{OH})_{4}\right](\mathrm{OH})_{12} \bullet 24 \mathrm{H}_{2} \mathrm{O}$.

The final difference-Fourier map is featureless: $\Delta \rho$ maximum and minimum were +1.68 and $-0.95 e / \AA^{3}$. The final coordinates and displacement parameters of the atoms, selected interatomic distances, and bondstrength calculations are reported in Tables 3, 4 and 5 respectively. On the basis of the bond-valence sums, a tentative scheme of hydrogen bonding is proposed. The interatomic distances between $\mathrm{O}$-atoms involved in $\mathrm{H}$ bonds are listed in Table 6 . The crystal structure of sturmanite, drawn by the program ATOMS (Dowty 1995), is shown in Figures 2 and 3. A table of structure factors is available from the Depository of Unpublished Data, CISTI, National Research Council of Canada, Ottaw, Ontario K1A 0S2, Canada.

\section{Discussion}

Two coaxial structural modules parallel to [001] can be considered as the most peculiar features of sturmanite. The basic one is a column of polyhedra formed by alternating $\left[\mathrm{Fe}(\mathrm{OH})_{6}\right]$ octahedra and triplets of ${ }^{\mathrm{VIII}} \mathrm{Ca}$ bearing polyhedra. The $\left[\mathrm{Fe}(\mathrm{OH})_{6}\right]$ octahedra are located along the three-fold axes, which pass through the origin of the cell. They are linked on both sides, by edge-sharing, to the triplets of ${ }^{\mathrm{VIII}} \mathrm{Ca}$-bearing polyhedra. Besides the $(\mathrm{OH})$ groups, which are shared between Fe-octahe-

TABLE 4. SELECTED INTERATOMIC DISTANCES $(\AA)$ IN THE STRUCTURE OF STURMANITE

\begin{tabular}{|c|c|c|c|c|c|}
\hline \multirow[t]{3}{*}{$\mathrm{Fe}(1)$} & $-O(1)$ & $1.98(1) \times 3$ & $\mathrm{Ca}(1)$ & $-O(1)$ & $2.37(1)$ \\
\hline & $-O(2)$ & $1.99(1) \times 3$ & & $-o(3)$ & $2.38(1)$ \\
\hline & & & & $-O(1)$ & $2.41(1)$ \\
\hline \multirow[t]{3}{*}{$\mathrm{Fe}(2)$} & $-O(4)$ & $1.93(1) \times 3$ & & $-O(3)$ & $2.44(1)$ \\
\hline & $-O(3)$ & $2.02(1) \times 3$ & & $-O(8)$ & $2.44(1)$ \\
\hline & & & & $-O(6)$ & $2.49(1)$ \\
\hline \multirow[t]{2}{*}{$\mathrm{S}(1)$} & $-O(16)$ & $1.43(1) \times 3$ & & $-O(10)$ & $2.64(2)$ \\
\hline & $-O(13)$ & $1.397(6)$ & & $-O(12)$ & $2.84(2)$ \\
\hline$O(13)$ & $-O(16)$ & $2.31(1) \times 3$ & & & \\
\hline \multirow[t]{2}{*}{$O(16)$} & $-O(16)$ & $2.33(2) \times 3$ & $\mathrm{Ca}(2)$ & $-O(5)$ & $2.32(1)$ \\
\hline & & & & $-O(4)$ & $2.42(1)$ \\
\hline \multirow[t]{2}{*}{$\mathrm{B}(1)$} & $-O(16)$ & $1.49(1) \times 3$ & &.$O(2)$ & $2.46(1)$ \\
\hline & & & & $-O(4)$ & $2.47(1)$ \\
\hline \multirow[t]{4}{*}{$\mathrm{S}(2)$} & $-O(17)$ & $1.46(1) \times 3$ & &.$O(7)$ & $2.50(1)$ \\
\hline & $-O(14)$ & $1.452(6)$ & & $-O(11)$ & $2.53(2)$ \\
\hline & {$[-O(14)$} & $1.451(6)]$ & & $-O(2)$ & $2.54(1)$ \\
\hline & {$\left[-O\left(17^{\prime}\right)\right.$} & $1.53(1) \times 3]$ & & $-O(9)$ & $2.70(2)$ \\
\hline$O(14)$ & $-O(17)$ & $2.35(1) \times 3$ & & & \\
\hline$O(17)$ & $-O(17)$ & $2.40(2) \times 3$ & $B(4)$ & $-O(19)$ & $1.51(1) \times 3$ \\
\hline$O\left(14^{\prime}\right)$ & $-O\left(17^{\prime}\right)$ & $2.53(1) \times 3$ & & $-O(20)$ & $1.458(6)$ \\
\hline \multirow[t]{2}{*}{$O\left(17^{\prime}\right)$} & $-O\left(17^{\prime}\right)$ & $2.39(3) \times 3$ & & {$\left[-O\left(19^{\prime}\right)\right.$} & $1.52(1) \times 3$ \\
\hline & & & & {$\left[-\mathrm{O}\left(20^{\prime}\right)\right.$} & $1.476(6)]$ \\
\hline \multirow[t]{2}{*}{$S(3)$} & $-O(15)$ & $1.420(6)$ & $O(19)$ & $-O(20)$ & $2.41(1) \times 3$ \\
\hline & $-O(18)$ & $1.42(1) \times 3$ & $O(19)$ & - $O(19)$ & $2.48(2) \times 3$ \\
\hline$O(15)$ & $-O(18)$ & $2.23(1) \times 3$ & $O\left(19^{\prime}\right)$ & $-O\left(20^{\prime}\right)$ & $2.42(1) \times 3$ \\
\hline$O(18)$ & $-O(18)$ & $2.39(2) \times 3$ & $O\left(19^{\prime}\right)$ & $-O\left(19^{\prime}\right)$ & $2.50(2) \times 3$ \\
\hline
\end{tabular}


TABLE 5. BOND-STRLNGIH CALCULATIONS FOR STURMANITE

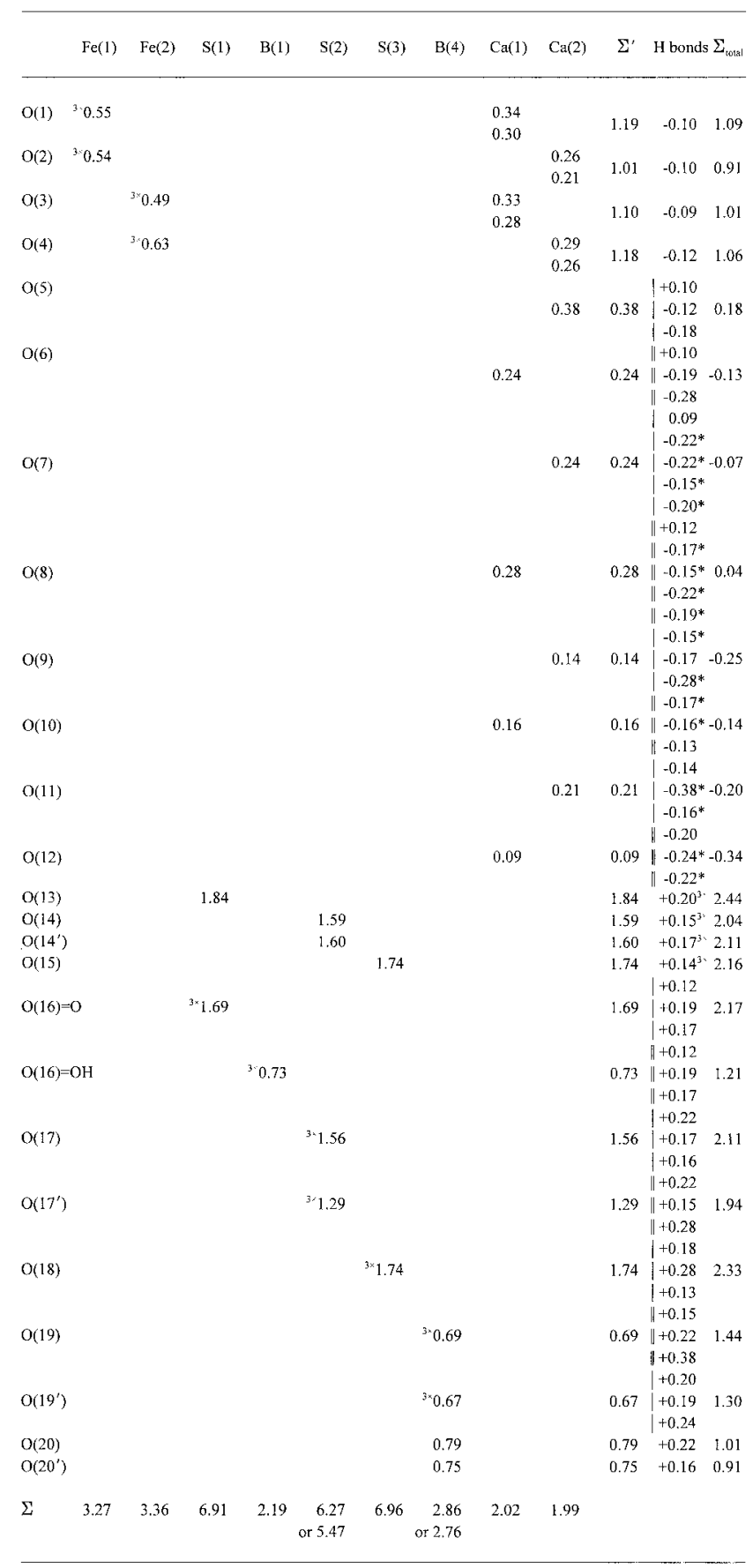

Notes: left and right " $3 \times$ " superscript means that the corresponding bond-valence has been considered three times in the vertical and horizontal sums, respectively, in keeping with the special positions (i.e., along the triads) of the atoms involved. Hydrogen bond-valences marked with an asterisk were considered at $50 \%$, in keeping with the partial occupancies of the atoms involved. Hydrogen bond having $O(16), O(19), O\left(19^{\prime}\right), O(20)$, and $O\left(20^{\prime}\right)$ as donor oxygen atoms have not been included in the bond-valence balance (therefore the bond-valence sums of atoms involved in those bonds are slightly incomplete). The parametcrs were taken from Brese \& O'Keeffe (1991) and Ferraris \& Ivaldi (1988). 


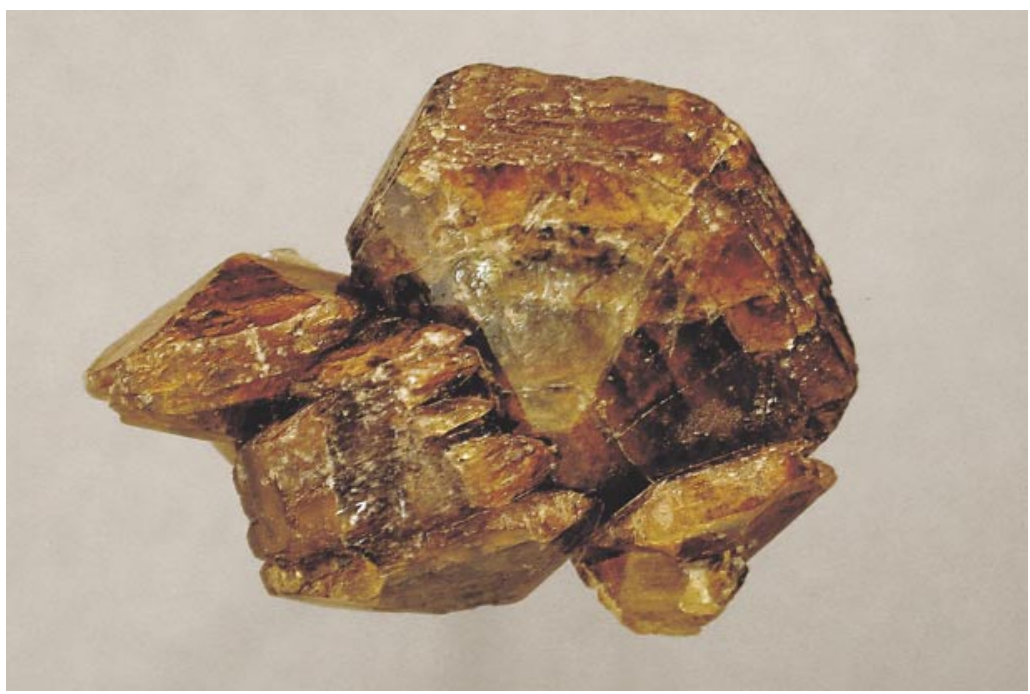

FIG. 1. Photo of sturmanite crystal. Size of specimen: $3 \times 2 \mathrm{~cm}$.

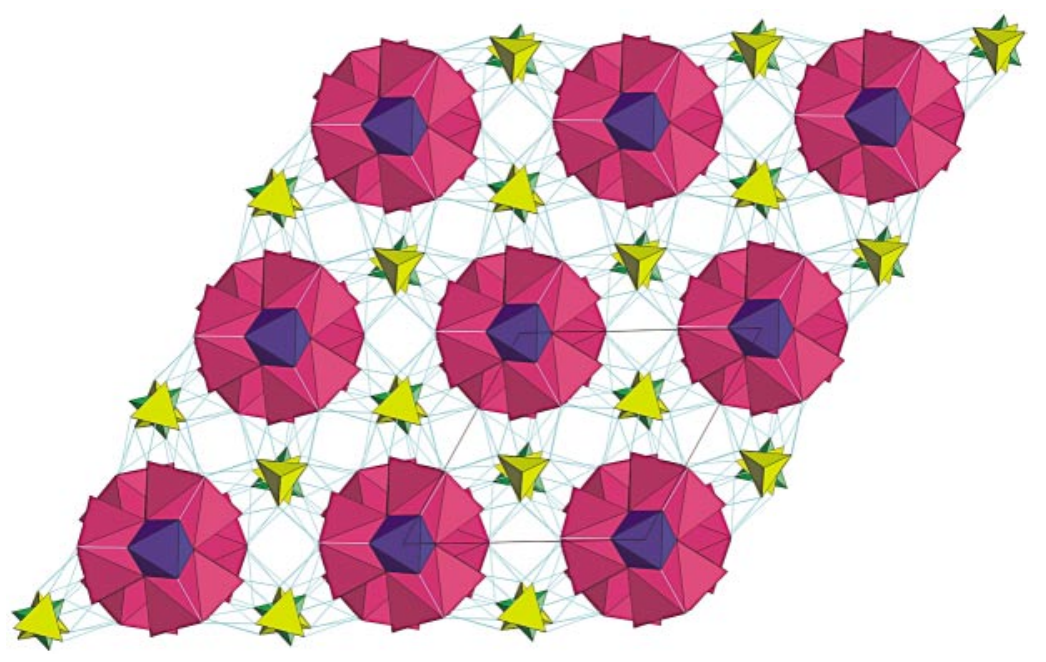

FIG. 2. The crystal structure of sturmanite projected onto (001). Ca-bearing polyhedra are red, Fe-bearing octahedra are blue, $\mathrm{SO}_{4}$ tetrahedra are yellow, $\mathrm{BO}_{4}$ tetrahedra are green, and $\mathrm{H}$-bonds are marked with greenish solid lines.

dra and Ca-polyhedra, each of the latter contains four $\mathrm{H}_{2} \mathrm{O}$ molecules, located on the outer surface of the columns.

The second structural module parallel to [001], whose configuration is more variable and less ordered owing to statistical orientation of the polyhedra, is formed of $\left[\mathrm{SO}_{4}\right]$ tetrahedra (partially replaced by $\left[\mathrm{B}(\mathrm{OH})_{3}\right]$ triangles) and by $\left[\mathrm{B}(\mathrm{OH})_{4}\right]$ tetrahedra and is located along the three-fold axes at $(1 / 3,2 / 3, z)$ and $(2 / 3,1 / 3$, $z)$. This module differs significantly from the corresponding module in ettringite. The $\left[\mathrm{S}(1) \mathrm{O}_{4}\right],\left[\mathrm{S}(2) \mathrm{O}_{4}\right]$ and $\left[\mathrm{S}(3) \mathrm{O}_{4}\right]$ tetrahedra are in the same sites as in ettringite; however, owing to the splitting of the $\mathrm{O}(14)$ positions, the $\left[\mathrm{S}(2) \mathrm{O}_{4}\right]$ tetrahedra are in two orientations that statistically replace each other: the first one [formed 
by one $\mathrm{O}(14)$ and three symmetrically equivalent $\mathrm{O}(17)]$ is the same as that in ettringite, whereas the second one [formed by one $\mathrm{O}(14)$ ' and three symmetrically equivalent $\left.\mathrm{O}(17)^{\prime}\right]$ is inverted with respect to the [001] direction. The $\left[\mathrm{S}(1) \mathrm{O}_{4}\right]$ tetrahedron is characterized by partial occupancy. Moreover, the $\mathrm{H}_{2} \mathrm{O}$ molecules in ettringite are replaced by $\left[\mathrm{B}(\mathrm{OH})_{4}\right]$ tetrahedra in sturmanite. Like the $\left[\mathrm{S}(2) \mathrm{O}_{4}\right]$ tetrahedra, the $\left[\mathrm{B}(4)(\mathrm{OH})_{4}\right]$ tetrahedra also are in two opposite orientations.

In connection with the variable composition of the second module in sturmanite, it is worthy of note that Pöllmann et al. (1989) discussed the isomorphous substitutions in synthetic compounds adopting the structure type of ettringite $\mathrm{Ca}_{6} \mathrm{Al}_{2} \mathrm{X}(\mathrm{OH})_{12} \cdot 24 \mathrm{H}_{2} \mathrm{O}$, where $\mathrm{X}=$ $\left(\mathrm{SO}_{4}\right)_{3}$ (ettringite), $\left(\mathrm{SO}_{4}\right)_{2}(\mathrm{OH})_{2},\left(\mathrm{CO}_{3}\right)_{3},\left[\mathrm{~B}(\mathrm{OH})_{4}\right]_{2}$ $(\mathrm{OH})_{4},\left[\mathrm{~B}(\mathrm{OH})_{4}\right]_{4}(\mathrm{OH})_{2}$, etc. They even predicted the stability of the hypothetical end-member with $\mathrm{X}=$ $\left[\mathrm{B}(\mathrm{OH})_{4}\right]_{6}$. In the IR spectra of B-bearing synthetic analogues of ettringite, bands at 950, 980 and 1185-1240 $\mathrm{cm}^{-1}$ are present, but the latter can be assigned to boron in three-fold coordination.

The two structural modules described above are linked to each other by a complex system of H-bonds, as shown in Figures 2 and 3. All O-atoms from $\left[\mathrm{SO}_{4}\right]$ tetrahedra, $\mathrm{OH}$ groups from $\left[\mathrm{B}(\mathrm{OH})_{3}\right]$ triangles, $\left[\mathrm{B}(\mathrm{OH})_{4}\right]$ tetrahedra and $\left[\mathrm{Fe}(\mathrm{OH})_{6}\right]$ octahedra, and all $\mathrm{H}_{2} \mathrm{O}$ molecules from Ca-polyhedra, are involved in these bonds. In the case of $\mathrm{O}(7)$ and $\mathrm{O}(8)$, four possible hydrogen bonds were located on the basis of $\mathrm{O}$... distances, which are interpreted to be due to a statistical occurrence of two different $\mathrm{H}_{2} \mathrm{O}$ molecules for both $\mathrm{O}(7)$ and $\mathrm{O}(8)$, in keeping with the partial occupancy of the acceptor oxygen atoms involved.

TABLE 6. INTERATOMIC DISTANCES BETWIEN O ATOMS INVOLVED IN HYDROGEN BONDS INVOLVING ANY O ... O PAIR IN STURMANITE

\begin{tabular}{lllllll}
\hline \multicolumn{1}{l}{ Interatomic distances $(\AA)$} & $v u$ & & & & \\
\end{tabular}

The first atom of oxygen quoted in an $O$..... O pair is the donor, the second is the acceptor $[\mathrm{O}-\mathrm{H} \ldots \mathrm{O}]$. The bond-valence contributions are quoted in valence units (vi).
The distribution of the hydrogen bonds allowed us to improve the bond-valence sums (Table 5) and to propose a tentative scheme of hydrogen bonds. Such a scheme is slightly incomplete, since a few contributions, namely the hydrogen bonds having $\mathrm{O}(16), \mathrm{O}(19)$, $\mathrm{O}\left(19^{\prime}\right), \mathrm{O}(20)$, and $\mathrm{O}\left(20^{\prime}\right)$ as donor oxygen atoms, are missing. The contribution of the hydrogen bonds to the bond-valence sums has been considered, in keeping with the site-occupancy factors (s.o.f.) of the atoms involved. Accordingly, all the bond valences of the hydrogen bonds marked with an asterisk in Table 5 were divided by two in the horizontal sums. The contribution of the hydrogen bonds to acceptor $\mathrm{O}(16)$ has been divided according to the s.o.f. of $\mathrm{S}(1)$ and $\mathrm{B}(1)$ atoms $(0.7$ and 0.3 , respectively), which are linked to $\mathrm{O}(16)$. Consequently, there are two rows in Table 5 , one for $\mathrm{O}(16)=$ $\mathrm{O}$ linked to $\mathrm{S}(1)$ and $\mathrm{O}(16)=\mathrm{OH}$ linked to $\mathrm{B}(1)$. Note that the bond-valence sum for $\mathrm{S}(2)$ (Table 5) is either of these two: i) with $\mathrm{O}(14)$ and $\mathrm{O}(17)=1.59+{ }^{3 \times} 1.56=$ 6.27 ; ii) with $\mathrm{O}\left(14^{\prime}\right)$ and $\mathrm{O}\left(17^{\prime}\right)=1.60+{ }^{3 \times} 1.29=5.47$. Both sums are reported in the last row of column $\mathrm{S}(2)$. For an analogous reason, a twofold sum occurs in the last row of column B(4). Overall, some deviations from ideal values occur in the bond-valence sums over cations, especially for sulfur, owing to some soft metrical constraints set at the final stages of the refinement, which resulted in shorter-than-usual S-O distances.

The important problem of composition of sturmanite is connected with the oxidation state of Mn. Unfortunately, the direct wet-chemical analysis of $\mathrm{Mn}^{2+}$, $\mathrm{Mn}^{3+}$ and $\mathrm{Mn}^{4+}$ is difficult because $\mathrm{Mn}$ can change its valency in the solution under mild conditions. Peacor $e t$ al. (1983) tentatively assigned a charge of $2+$ to the manganese, although the presence of $\mathrm{Fe}^{3+}$ and $\mathrm{Al}^{3+}$ suggests that the $\mathrm{Mn}$ in this structure might be present with a higher oxidation state. It is well known that the ion $\mathrm{Mn}^{3+}$ is a strong chromophore. The deep-purple color of purpurite and piemontite is due to the presence of this ion. In a mineral of the ettringite group, jouravskite, $\mathrm{Ca}_{6} \mathrm{Mn}^{4+}{ }_{2}\left(\mathrm{SO}_{4}, \mathrm{CO}_{3}\right)_{4}(\mathrm{OH})_{12} \cdot 26 \mathrm{H}_{2} \mathrm{O}, \mathrm{Mn}$ is assumed to be tetravalent (see also Gaudefroy \& Permingeat 1965). The color of jouravskite is greenish to yellow. The investigated specimen of sturmanite is also brownish yellow. Moreover, jouravskite is known to occur at the same Mn deposits of South Africa in which sturmanite was found. All these observations allowed us to consider that the $\mathrm{Mn}$ in sturmanite may well be in the $\mathrm{Mn}^{4+}$ oxidation state. The ionic radius of six-fold-coordinated $\mathrm{Mn}^{4+}$ is $0.54 \AA$. In some cases, substitution of $\mathrm{Fe}^{3+}$ by $\mathrm{Mn}^{4+}$ is possible. For example, in feroxyhyte (idealized formula $\mathrm{FeOOH}$ ), the ratio $\mathrm{Mn}^{4+}: \mathrm{Fe}^{3+}$ varies from 0 up to 1 . Consequently, the real formula of this mineral is $\mathrm{Fe}^{3+}{ }_{1-x} \mathrm{Mn}^{4+}{ }_{x} \mathrm{O}_{1+x}(\mathrm{OH})_{1-x}$ and it was established using the combination of electron microdiffraction and X-ray spectroscopy. 


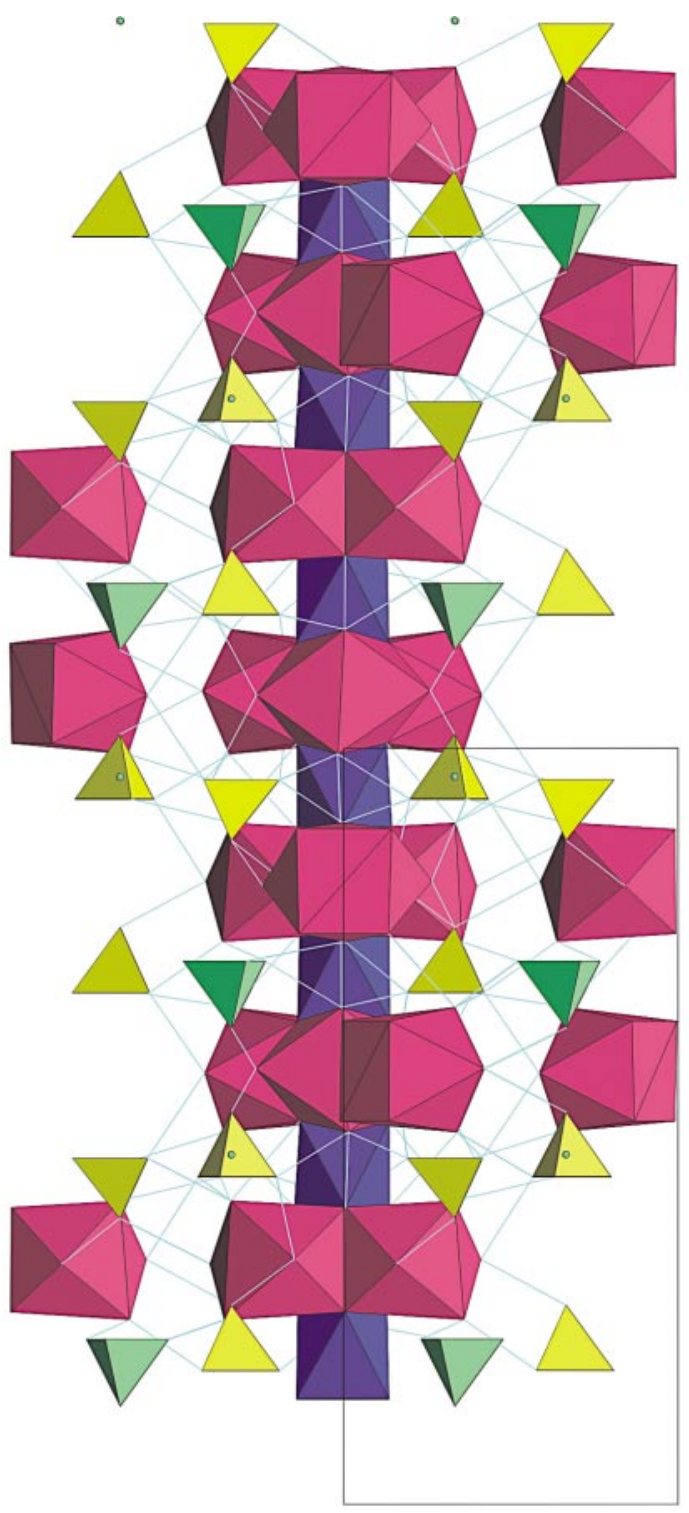

FIG. 3. A view of the structure of sturmanite, emphasizing the columns running parallel to [001] formed by Ca-bearing polyhedra and $\mathrm{Fe}$-bearing octahedra. The $\mathrm{SO}_{4}$ and $\mathrm{BO}_{4}$ tetrahedra are linked to the column by H-bonds.

\section{ACKNOWLEDGEMENTS}

This work was supported in part by the Russian Scientific Foundation (Grant 03-05-64054 ), by Grant MK-1046.2004.5, by the Grant No. 1642.2003.5 of the Fundamental Science School Program and by the Russian Universities Programme. M. Pasero and S. Merlino acknowledge the support by MIUR (40\% grant). A grant for a research stay in Pisa Project 1, Enclosure 3: "Crystal structures and topology of rare and new minerals" within the framework of the agreement for scientific and technological cooperation between Italy and Russia is also gratefully acknowledged. The authors thank Drs. I. Grey, T. White, and R.F. Martin for their helpful suggestions.

\section{REFERENCES}

BRESE, N.E. \& O'KeEFFE, M. (1991): Bond-valence parameters for solids. Acta Crystallogr. B47, 192-197.

DowTy, E. (1995): Atoms 3.2, a Computer Program for Displaying Atomic Structures. Kingsport, Tennessee.

Dunn, P.J., Peacor, D.R., Leavens, P.B. \& Baum, J.L. (1983): Charlesite, a new mineral of the ettringite group from Franklin, New Jersey. Am. Mineral. 68, 1033-1037.

FERRARIs, G. \& Ivaldi, G. (1988): Bond valence vs. bond length in $\mathrm{O}$... O hydrogen bonds. Acta Crystallogr. B44, 341-344.

Gaudefroy, C. \& Permingeat, F. (1965): La jouravskite, une nouvelle espèce minérale. Bull. Soc. fr. Minéral. Cristallogr. 88, 254-262.

Malinko, S.V., Chukanov, N.V., Dubinchuk, V.T., Zadov A.E. \& Koporulina, E.V. (2001): Buryatite, $\mathrm{Ca}_{3}\left(\mathrm{Si}_{2} \mathrm{Fe}^{3+}\right.$ $\mathrm{Al})\left[\mathrm{SO}_{4}\right](\mathrm{OH})_{5} \mathrm{O} \bullet 12 \mathrm{H}_{2} \mathrm{O}$, a new mineral. Zap. Vser. Mineral. Obshchest. 130(2), $72-78$ (in Russ.).

MERLINO, S. \& ORLANDI, P. (2001): Carraraite and zaccagnaite, two new minerals from the Carrara marble quarries: their chemical compositions, physical properties, and structural features. Am. Mineral. 86, 1293-1301.

MoORE, A.E. \& TAYLOR, H.F.W. (1970): Crystal structure of ettringite. Acta Crystallogr. B26, 386-393.

Peacor, D.R., Dunn, P.J. \& Duggan, M. (1983): Sturmanite, a ferric iron, boron analogue of ettringite. Can. Mineral. 21, 705-709.

Pöllmann, H., Kuzel, H.-J. \& Wenda, R. (1989): Compounds with ettringite structure. Neues Jahrb. Mineral., Abh. 160, 133-158.

SHELDRICK, G.M. (1997): SHELXL97, a Program for the Solution and Refinement of Crystal Structures. Univ. of Göttingen, Göttingen, Germany.

Received August 29, 2003, revised manuscript accepted April 22, 2004. 